\title{
The influence of xenobiotics in river sediment on the reproduction and survival of Daphnia magna, 1820, Straus
}

\author{
Influência de xenobióticos no sedimento de rio sobre a reprodução \\ e a sobrevivência de Daphnia magna, 1820, Straus
}

Silvana Pereira Gonçalves, Fabiane Lucheta, Viviane Kelin de Souza and Nara Regina Terra

Fundação Estadual de Proteção Ambiental Henrique Luis Roessler - FEPAM, Av. Dr. Salvador França, 1707, Jardim Botânico, CEP 90690-000, Porto Alegre, RS, Brazil e-mail: silvana.goncalves@acad.pucrs.br; fabianelucheta@hotmail.com; vivi_kelin@hotmail.com; nara.terra@ufrgs.br

\begin{abstract}
Aim: The Taquari River, a tributary of Guaíba Lake, is a major economic and environmental source for Rio Grande do Sul, a state located in the far south of Brazil; Methods: This study evaluated the interference of sediment from this river in the reproduction and survival of 320 microcrustaceans ( 80 organisms per site) of the Daphnia magna species. Four sites between the middle course and the river mouth were monitored using eight samples from each site, between June/06 and April/10. Mortality higher than $20 \%$ suggested the acute action of the sample on the daphniids, while low reproduction indicated the presence of chronic toxicity. Sometimes an effect on survival was noted, but the number of individuals generated was always low. Semistatic chronic assays ( 21 day) were developed in $50 \mathrm{~mL}$ beakers using sediment and M4 culture medium at a ratio of 1:4 (v:v). Each beakers received a microcrustacean born from lots presenting LC50-24 hours $=0.98 \mathrm{mg} \mathrm{K}_{2} \mathrm{Cr}_{2} \mathrm{O}_{7} \pm 0.04 \mathrm{mg}$ totaling ten replicas per sample. The assays were developed under controlled light (16 hours light/day) and temperature $\left(20^{\circ} \mathrm{C} \pm 2{ }^{\circ} \mathrm{C}\right)$ conditions; Results: Duncan test showed a variation in reproduction $(\mathrm{p}<0.05)$ with the presence of chronic toxicity. There was less reproductive activity in $91 \%$ of the samples, while for survival the reduction attained $9 \%$. Spearman correlation identified the dependence between the rainfall index and reproduction in one of the samples and was absent when the rainfall index was compared to survival; Conclusions: Taquari River presented episodes of toxicity, and it is necessary to continue studies in the area and to inspect local sources of pollution, as already has been done. Chronic bioassays should be maintained when the purpose is to evaluate environmental quality, since reproduction proved more sensitive than survival.
\end{abstract}

Keywords: bioassays, reproduction, survival, cladocerans, sediments.

Resumo: Objetivo: $\mathrm{O}$ rio Taquari, tributário do Lago Guaíba, constitui importante fonte econômica e ambiental para o Rio Grande do Sul, estado localizado no extremo sul do Brasil; Métodos: $\mathrm{O}$ presente estudo avaliou a interferência do sedimento deste rio na reproduçáo e na sobrevivência de 320 microcrustáceos ( 80 organismos por local) da espécie Daphnia magna. Foram monitorados quatro locais entre o curso médio e a foz do rio, utilizando oito amostras de cada local, entre junho/06 e abril/10. Mortalidade superior a $20 \%$ sugeriu ação aguda da amostra sobre os daphniids, enquanto a baixa reprodução indicou presença de toxicidade crônica. Eventualmente foi observado efeito na sobrevivência, porém a pequena geração de indivíduos foi constante. Ensaios crônicos (21 dias) semi-estáticos foram desenvolvidos em béqueres de $50 \mathrm{~mL}$ utilizando sedimento e meio de cultivo M4 na relaçáo de 1:4 (v:v). Cada béquer recebeu um microcrustáceo nascido de lotes apresentando LC50-24 horas $=0,98 \mathrm{mg} \mathrm{K}_{2} \mathrm{Cr}_{2} \mathrm{O}_{7} \pm 0,04 \mathrm{mg}$ totalizando dez réplicas por amostra. Os ensaios desenvolveram-se em condiçóes controladas de iluminação (16 horas luz diárias) e temperatura $\left(20^{\circ} \mathrm{C} \pm 2{ }^{\circ} \mathrm{C}\right)$; Resultados: $\mathrm{O}$ Teste de Duncan mostrou variação na reproduçâo $(\mathrm{p}<0.05)$ com presença de toxicidade crônica. Ocorreu redução na atividade reprodutiva em $91 \%$ das amostras, enquanto que para sobrevivência a redução alcançou 9\%. A correlaçáo de Spearman identificou dependência entre índice pluviométrico e reproduçáo em uma das amostras e esteve ausente quando o índice pluviométrico foi comparado com a sobrevivência; Conclusóes: $\mathrm{O}$ rio Taquari apresentou episódios de toxicidade sendo necessários estudos na área e fiscalização das fontes poluidoras locais como já vem sendo realizado. Bioensaios crônicos devem ser mantidos quando o objetivo for a avaliação da qualidade ambiental, já que a reprodução foi mais sensível que a sobrevivência.

Palavras-chave: bioensaios, reprodução, sobrevivência, cladóceros, sedimentos. 


\section{Introduction}

Bioassays are often used as tools to evaluate environmental quality for environmental preservation and quality of human life. Bioindicators in sediment samples have been increasingly used when the purpose is to know the quality of water resources. The Taquari River, located in the northeast of Rio Grande do Sul, the southernmost state of Brazil, is one of the tributaries of Guaiba Lake, wich is important for Porto Alegre, the state capital, and surrounding areas. Taquari River basin covers $26,428 \mathrm{~km}^{2}$ distributed through ten municipalities (Ferreira and Both, 2004). The river is $500 \mathrm{~km}$ long, and along its course it receives contamination originating in sanitary and industrial sewage, sand dredging, navigation and lumber processing, although it is used as a source of water supply for the human population. Xenobiotics that reach the rivers may be deposited as sediment, be transported by the current, assimilated by living beings or recycled due to biological activity. Weltens et al. (2000) said that contaminated particles have toxic power, not only because they are continuous sources of dissolved xenobiotics, but also because metals and fractions that compose the food become available inside the body of the daphniids. Yu and Wang (2002) recorded the release of metals into the environment, through cladoceran molting.

Agriculture, another vocation of the Taquari River valley, contaminates the river course with different agricultural pesticides and herbicides (pyrethroid, organochlorines, and organophosphates) at different levels, ranging from extremely toxic to only mildly toxic (CRQ, 2008). Besides these agents, close to the mouth of this river, in 1960, a plant was established to exploit, produce, preserve and manufacture poles for electricity and wood derived products, using pentachlorophenol, creosote and CCA (CopperChromium-Arsenic) among others.

Local geology and deforestation favor rainfall runoff. Together with the soil carried off by torrential rainfall in the Taquari River valley, pesticides, livestock and domestic products derived from human activity are transported (Zanotelli et al., 2004). According to Reis et al. (2010) mountain rivers play an important role in sediment transport, since they have a smaller storage capacity and a rapid response to precipitation peaks, carrying sediment loads associated with pollutants. Besides, the author emphasizes the importance of soil particles containing associated metals that are entrained into the river bed. Substances of anthropic origin retained in the sediment may be released due to the variation in the current or local biological activities, constituting a major source of contaminants for the water mass. These characteristics are present in the Taquari River.

Daphnia magna was the test-organism used in order to obtain reliable answers in environmental studies. Cladocerans in general absorb toxic compounds in the sediment through particle ingestion, since they are non-selective filterers (Weltens et al., 2000). Laboratory experiments can identify, in the test-organisms, effects triggered by xenobiotics present in the samples, even when it is impossible to identify what causes this. Time of exposure and feeding habits are essential in the cladoceran response process. Work done with sediment samples emphasizes the importance of the time of exposure in relation to the concentration of a toxics for organism response (Robinson et al., 2010), although Weltens et al. (2000) say that small doses of contaminants are enough to cause damage in D. magna. Ren et al. (2009, 2009a) relate the level of response of this species to the degree of contamination and time of exposure to the toxics. Substances retained in the sediment are released due to the alimentary habit of this species, since individuals $\geq 48$ hours old graze on the surface mobilizing persistent pollutants deposited on the river bed (Suedel et al., 1996), characterizing it as a major indicator of environmental quality. Gillis et al. (2006) found a that the survival of this cladoceran was reduced by up to $50 \%$ when exposed to the contaminated sediment sample.

The purpose of this study was to evaluate the adverse effects of sediment samples from the Taquari River on the reproductive process and on the survival of $D$. magna, aiming at supplying information that can help in projects for the recovery of this water resource.

\section{Material and Methods}

Taquari river belongs to Class 2 from the headwaters to the mouth and waters of this Class are used for primary contact recreation and human consumption after conventional treatment, according to Brazilian Law (CONAMA, 2005). Between June/06 and April/10 eight sediment samples were collected at four sites in Taquari River (Figure 1). The use of the two initials of the river name (Ta), followed by the distance from the mouth identified each site. Table 1 shows the points with the geographical coordinates and main sources of contamination. 


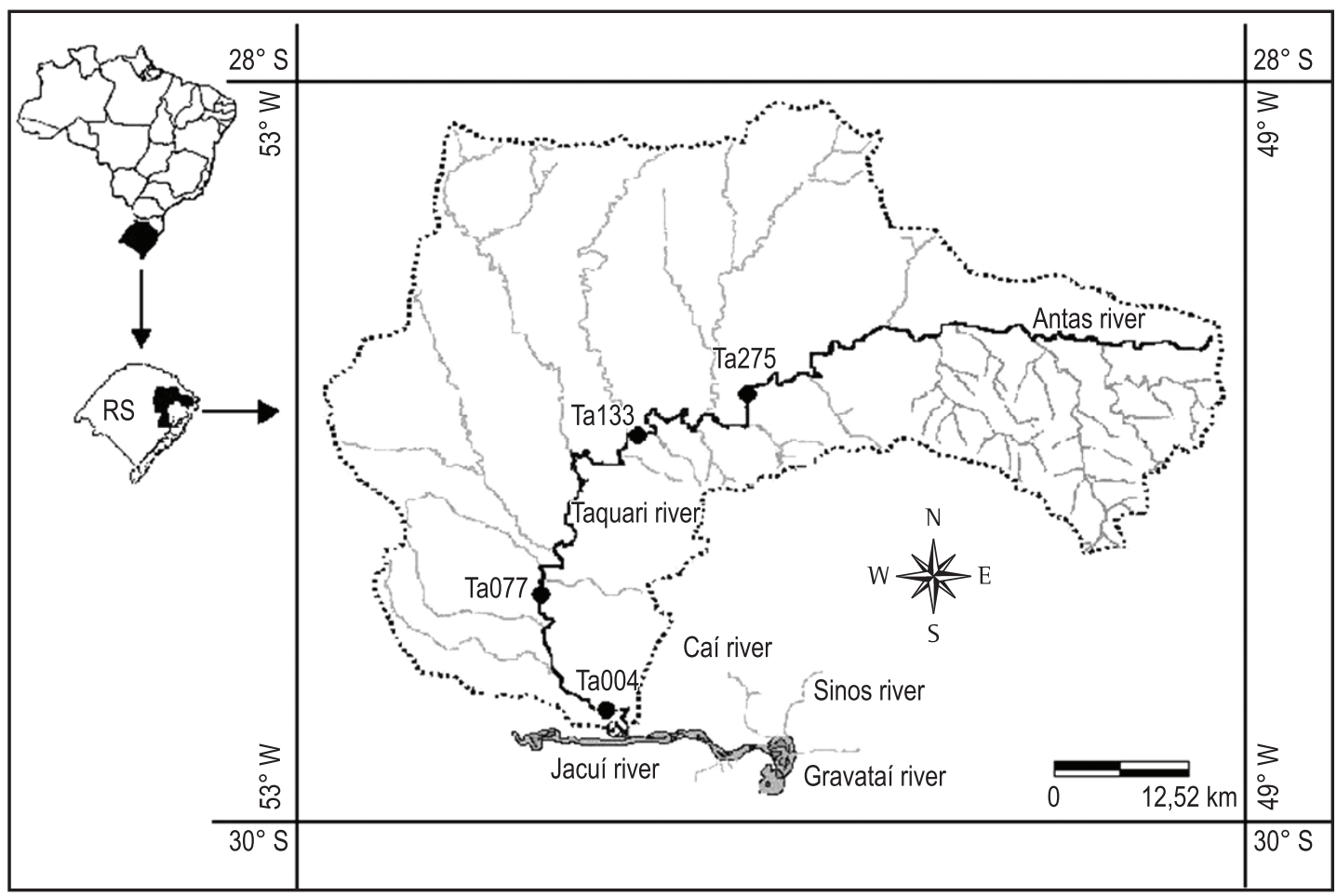

Figure 1. Sampling stations in the Taquari-Antas Hydrographic Basin, Rio Grande do Sul, Brazil.

Table 1. Identification of the sampling sites and main sources of contamination.

\begin{tabular}{|c|c|c|}
\hline Name & Geographical coordinates & Sources of pollutants \\
\hline Ta275 & $29^{\circ} 00^{\prime} 45,2^{\prime \prime} \mathrm{S}$ and $51^{\circ} 22^{\prime} 00,5^{\prime \prime} \mathrm{W}$ & Industrial and sanitary effluents, agriculture and \\
\hline Ta133 & $29^{\circ} 13^{\prime} 35,1^{\prime \prime} \mathrm{S}$ and $51^{\circ} 51^{\prime} 06,4^{\prime \prime} \mathrm{W}$ & Sanitary sewage, tannery effluents an \\
\hline Ta077 & $29^{\circ} 30^{\prime} 41,9^{\prime \prime} \mathrm{S}$ and $51^{\circ} 58^{\prime} 47,5^{\prime \prime} \mathrm{W}$ & $\begin{array}{l}\text { Sanitary sewage, tannery effluents, meat-packing plants, brewery and } \\
\text { navigation }\end{array}$ \\
\hline Ta004 & $29^{\circ} 55^{\prime} 45,2^{\prime \prime} \mathrm{S}$ and $51^{\circ} 43^{\prime} 50,4^{\prime \prime} \mathrm{W}$ & Navigation, sand dredging, wood processing and sanitary sewage \\
\hline
\end{tabular}

Sediment was sampled using a Petersen grab at a depth of $1.20 \mathrm{~m}$. Samples placed in thermal boxes containing ice were transported to the laboratory where they were stored in the dark at $4{ }^{\circ} \mathrm{C}$ until the beginning of procedures (Suedel et al., 1996). The experiments were performed within up to a month after sampling. Bulk sediment was used in the assays, after larger animals were removed with pincers, avoiding the interference of indigenous organisms in the responses.

Lots (LC50-24 hours $=0.98 \mathrm{mg} \mathrm{K}_{2} \mathrm{Cr}_{2} \mathrm{O}_{7}$ $\pm 0.04 \mathrm{mg}$ ) containing 25 individuals per $1000 \mathrm{~mL}$ of culture medium M4 (Elendt and Bias, 1990), kept in a germinator programmed for 16 hours of light a day and $20{ }^{\circ} \mathrm{C} \pm 2{ }^{\circ} \mathrm{C}$ (ABNT, 2004) originated the test-organisms. Trimmed SpearmanKarber Method was used to calculate sensitivity (Hamilton et al., 1977).

Changes in the reproduction and survival of 80 microcrustaceans were the endpoints to evaluate sediment quality at each site. At the beginning of the exposures, the cladocerans were between 2 and 26 hours old (ABNT, 2004).

Beakers $(50 \mathrm{~mL})$, covered with laboratory film, were used as test-containers and, after receiving the sample they were kept refrigerated in the dark until the M4 was added (pH: 7.8; hardness: $230 \mathrm{mg}$ $\left.\mathrm{CaCO}_{3} / \mathrm{L}\right)$. The beakers containing sediment and M4 (1:4; v:v) (Suedel et al., 1996; Terra et al., 2008) remained overnight in a germinator in order to become acclimated. The next morning, ten microcrustaceans were added randomly, per sample, distributed one by one into each beaker. A control group submitted to the same conditions as the samples accompanied these assays with exposed only to the M4 medium. Test-organisms and lots were kept under the same conditions but in separate germinators to avoid contamination.

Mortality (total absence of movement) and reproduction were observed on Mondays, 
Wednesdays and Fridays. Living neonates were recorded and discarded. Old M4 was replaced by fresh culture medium, avoiding breaking the upper sediment layer. Then adult daphniids were returned to the beakers of origin and fed with Desmodesmus subspicatus algae (Chodat, 1926) Hegewald and Schmidt, $2000\left(0.7 \mathrm{~mL} ; 10^{7}{\left.\text { cells. } . \mathrm{cm}^{-3}\right)}^{-3}\right.$ and fermented fish chow, complemented by biological yeast $(0.1 \mathrm{~mL})$ according to the ABNT NBR 12713 standard (2004). These amounts of food supply the nutritional needs of the testorganism until the next observation.

Percentage survival and mean number of neonates per brood were calculated to evaluate the impact of samples on the cladocerans. In healthy environments $\geq 80 \%$ live individuals were expected and a mean of $\geq 20$ neonates per brood. ANOVA (two factors) and Duncan Test compared the reproductive mean in time and between points; ANOVA (single factor) and T-test were used to compare the total number of neonates per site. Spearman correlation evaluated the relationship between survival, reproduction and rainfall data.

Results obtained from physical, chemical and bacteriological analyses and analyses of metals in water sampled at the same time as the sediment were considered helpful to interpret the bioassays. Local sources of pollution defined the parameters to be evaluated. Nitric acid $(5 \mathrm{~mL})$ was added in dark glass flasks $(1000 \mathrm{~mL})$ with samples of water to dose heavy metals. Wide-mouthed borosilicate flasks $(100 \mathrm{~mL})$ were used for microbiological sampling. Physical and chemical parameters followed the methodology advocated in APHA (1992) both for collection and for analysis. Acid digestion of samples and determination by Flame Atomic Absorption Spectrophotometry were used for the verification, of the presence of total heavy metals; Multiple Tubes and Chromogenic Substrate Test identified coliforms. Dissolved oxygen (DO) and $\mathrm{pH}$ assessments were obtained from direct readings performed with appropriate equipment, Oximeter and Potentiometer, respectively.

Heavy metals, even below the allowed limit or during a month when no sediment sampling was performed, were considered because they belong to the group of persistent xenobiotics. Physical, chemical and bacteriological parameters were related to the data only when present at values discrepants the value legally allowed at the time of sediment sampling.

Rainfall indices of the period of study provided by the Rio Grande do Sul Civil Defense (Defesa Civil) were used to complement the study.

\section{Results}

At least $80 \%$ test organisms were found alive until the end of observations only at Ta275 in all samplings. At the other sites mortality was higher than $20 \%$ in a sample of each site (Ta004 and Ta 133 in Apr./09; Ta077 in Dec./09) corresponding to $12.5 \%$ (Figure 2).

On several occasions the phenols and total phosphorus $(\mathrm{P})$ surpassed the national legal limit (CONAMA, 2005) at the three points with recorded acute toxicity. The mean of $\mathrm{P}$ was above the allowed level at the four sites, whereas for Phenol it exceeded the permitted level only at Ta77, although

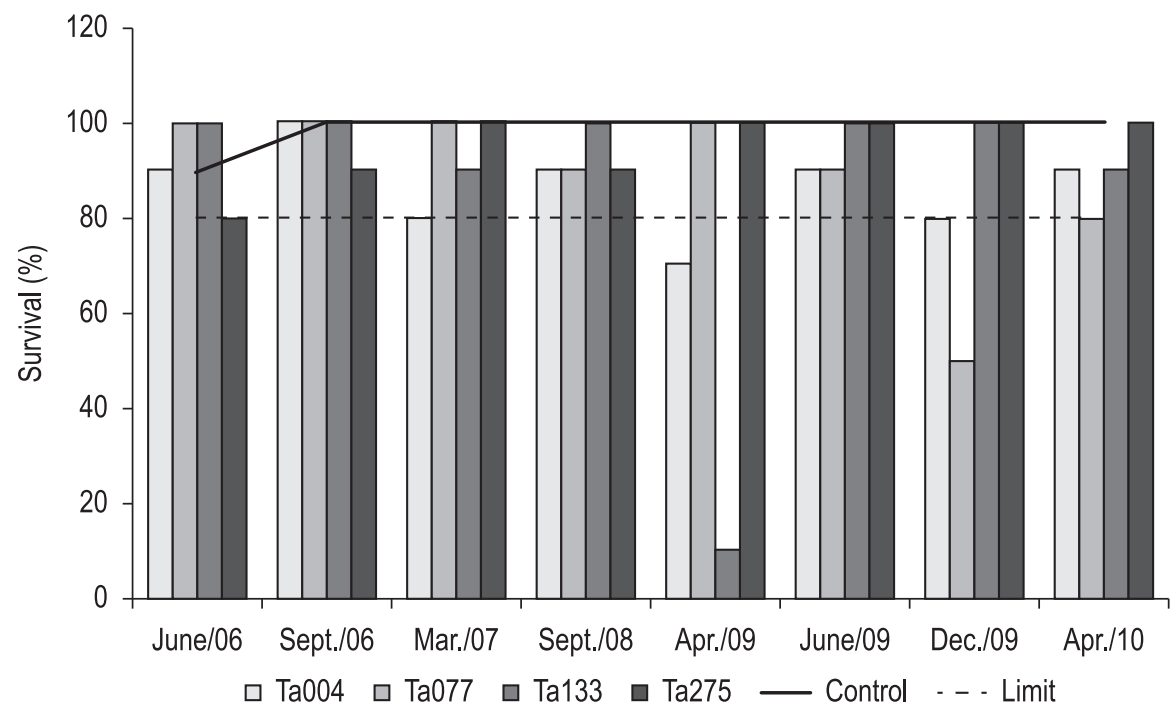

Figure 2. Percentage of test-organism survival per month of sampling. The broken line indicates the percentage survival expected $(\geq 80 \%)$. 
some results brought the standard deviation above the legal limit at all sites (Figure 3).

Action in survival was detected in the month with the lowest rainfall index at $\mathrm{Ta} 004$ and Ta133 (both with $10 \mathrm{~mm}$ ) and with the highest index at Ta077 (136 mm). Spearman correlation, however, was absent $(p \leq 0.05)$ compared to survival between the sites and survival with rainfall index.

Sediment samples from Taquari River reduced the neonate production in $91 \%$ of the assays. Only Ta004 (Dec./09) and Ta077 (June/06; Apr./10) achieved the expected mean for births. Figure 4 shows the clusters defined based on reproduction, applying Duncan Test: two at Ta004 and three at the other sites.
The single factor ANOVA showed a difference between the site variances considering the total number of neonates. Later, using T-test, the groups were compared two by two and each group was compared to the control pointing to a significant difference $(p<0.05)$ between the control group and the others.

Lower means of neonates were found at Ta133 and Ta275. While Ta077 had a higher mean number of births (710), the lowest (548) occurred at Ta133. $\mathrm{Ta} 004$ and Ta275 presented intermediate means, 666 and 568, respectively. The lowest standard deviation for these numbers was found at Ta275 (112.06) and the highest at Ta133 (269.06). Ta004

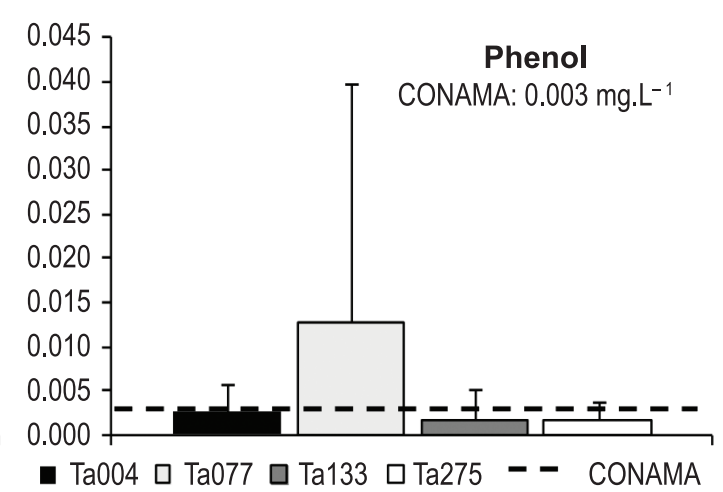

Figure 3. Mean and standard deviation of Total Phosphorus and Phenol per sampling site.
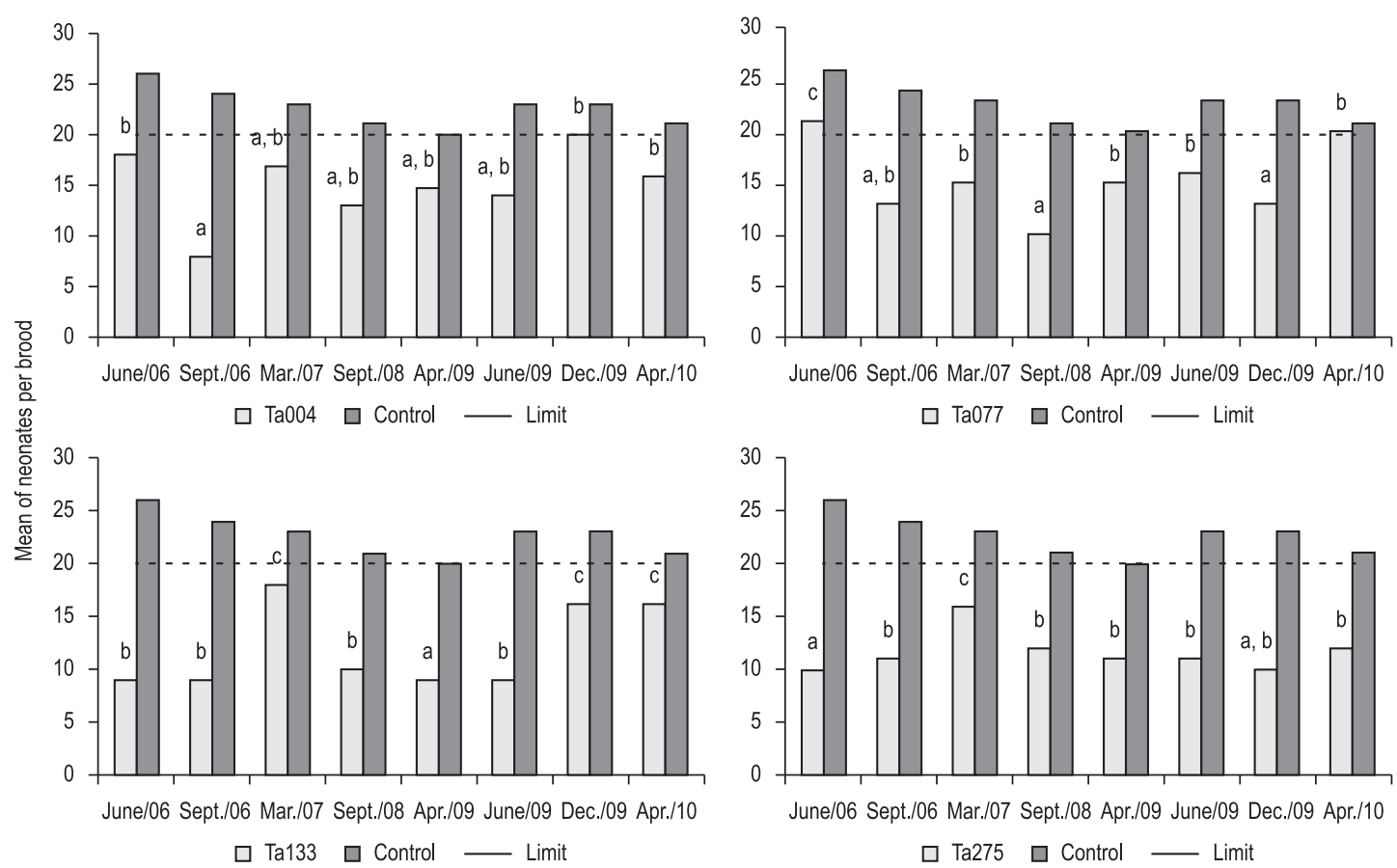

Figure 4. Mean births per brood. Different letters indicate a significant difference between the births $(\mathrm{p}<0.05)$. 
(147.87) and $\mathrm{Ta} 077$ (201.19) showed intermediate deviations (Figure 5).

The variations of the monthly reproductive means between points, calculated using the Duncan Test showed a few months with uniform responses from the headwaters to the mouth, and others with a difference in the number of neonates. The samples of June/06, Sept./06, Apr./09 and June/09 induced a greater variation between sites, with three clusters followed by Sept./08 and Dec./09 with two, while Mar./07 and Apr./10 were uniform. Table 2 shows the result of the analysis of interaction between factors (site and month), distributed by sites. Different letters in the table indicate significant differences $(p<0.05)$ between the monthly reproductive means.

Bacteriological and physicochemical analyses in water samples, performed at the same time as sediment collection, were not in conformity with Brazilian Law (CONAMA, 2005) for Escherichia coli (EC) (Ta133, Dec./09), Dissolved Oxygen (DO) (Ta275, June/06), Hydrogen
Potential (pH) (Ta275, June/06), Phosphorus (P) (Ta004, June/06, Sept./08, Apr./09 and Dec./09; Ta077, June/06, Sept./06, Sept./08, Apr./09 and Dec./09; Ta133, June/06, Sept./08, Apr./09 and Dec./09; Ta275, June/06, Sept./08 and Dec./09) and Phenols (Ta004, June/06 and Sept./08; Ta077, Mar./07; Ta133, Apr./09; Ta275, Sept./08).

The Ta275 sample in June/06 induced the lowest generation of young (402) at this site in the period sampled, coinciding with the higher volume of local rainfall $(202 \mathrm{~mm})$. On the other hand, the sample from Ta133 in Mar./07 produced the highest number of neonates (836) at this site in the month with the greatest rainfall. However, the Spearman Correlation was only detected at Ta133, considering rainfall and reproduction. At Ta077 (June/06) the highest production of neonate among all samples $(1,040)$ occurred. Delay at the beginning of the reproductive activity was observed on several occasions. Table 3 shows time of exposure of the cladocerans at the time of the first brood and the physical, chemical and metal parameters which

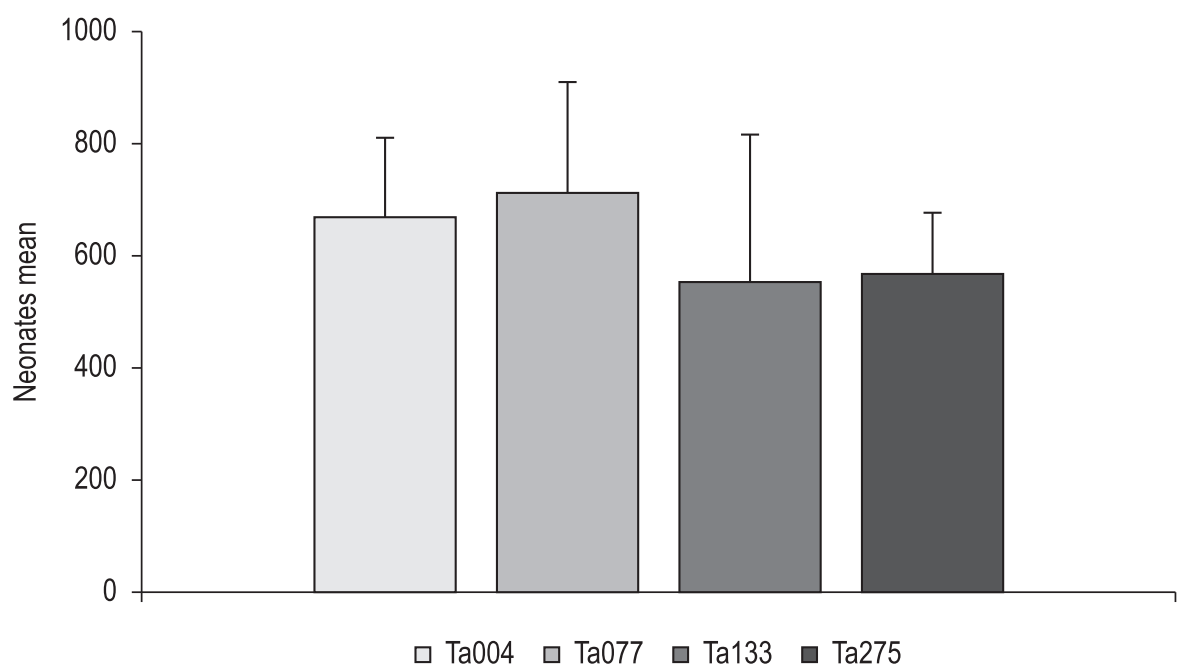

Figure 5. Means of neonates considering the total births per site.

Table 2. Multiple comparison of the mean monthly births at each site. Means with the same letter do not differ significantly $(\mathrm{p}<0.05)$. C- comparison.

\begin{tabular}{|c|c|c|c|c|c|c|c|}
\hline \multicolumn{2}{|c|}{ June/06 } & \multicolumn{2}{|c|}{ Sept./06 } & \multicolumn{2}{|c|}{ Mar./07 } & \multicolumn{2}{|c|}{ Sept./08 } \\
\hline Site & Mean & Site & Mean & Site & Mean & Site & Mean \\
\hline Ta275 & $40.2^{a}$ & Ta004 & $38.3^{a}$ & Ta004 & $68.8^{a}$ & Ta077 & $46.7^{a}$ \\
\hline Ta133 & $47^{a}$ & Ta133 & $44.6^{a, b}$ & $\mathrm{Ta} 077$ & $75^{a}$ & Ta133 & $50^{\mathrm{a}, \mathrm{b}}$ \\
\hline Ta004 & $82.2^{b}$ & Ta275 & $54.6^{\mathrm{b}, \mathrm{c}}$ & Ta275 & $79.9^{a}$ & Ta275 & $58.2^{\mathrm{a}, \mathrm{b}}$ \\
\hline Ta077 & $104^{c}$ & $\mathrm{Ta} 077$ & $62.9^{c}$ & Ta133 & $83.6^{a}$ & $\mathrm{Ta004}$ & $64.3^{\mathrm{b}}$ \\
\hline \multicolumn{2}{|c|}{ Apr./09 } & \multicolumn{2}{|c|}{ June/09 } & \multicolumn{2}{|c|}{ Dec./09 } & \multicolumn{2}{|c|}{ Apr./10 } \\
\hline Site & Mean & Site & Mean & Site & Mean & Site & Mean \\
\hline Ta133 & $4.4^{\mathrm{a}}$ & Ta133 & $45.7^{a}$ & Ta077 & $41.9^{a}$ & Ta275 & $59.2^{\mathrm{a}}$ \\
\hline Ta004 & $54.5^{b}$ & Ta275 & $57^{a}$ & Ta275 & $49.6^{a}$ & $\mathrm{Ta} 004$ & $74.1^{\mathrm{a}}$ \\
\hline Ta275 & $56.8^{\mathrm{b}, \mathrm{c}}$ & Ta004 & $67.7^{\mathrm{b}, \mathrm{c}}$ & Ta133 & $82.4^{b}$ & Ta133 & $80.6^{a}$ \\
\hline Ta077 & $76.7^{c}$ & Ta077 & $78.5^{c}$ & Ta004 & $83.1^{\mathrm{b}}$ & Ta077 & $82.7^{a}$ \\
\hline
\end{tabular}


Table 3. Delay of reproductive activity related to physical, chemical and metal parameters which were not in accordance with Brazilian Law (CONAMA, 2005).

\begin{tabular}{ccccc}
\hline Month & Site & Days & Parameters & Metals ( $)$ \\
\hline June/06 & Ta133 & 13 & $\mathrm{P} \uparrow$ & $\mathrm{Fe}, \mathrm{Mn}$ \\
& Ta 275 & 13 & $\mathrm{P} \uparrow \mathrm{pH} \uparrow \mathrm{DO} \downarrow$ & $\mathrm{Al}, \mathrm{Fe}$ \\
Sept./06 & Ta004 & 12 & & $\mathrm{Al}, \mathrm{Fe}, \mathrm{Cu}$ \\
Mar./07 & Ta 275 & 12 & $\mathrm{Al}, \mathrm{Fe}$ \\
Sept./08 & Ta004 & 12 & $\mathrm{P} \uparrow$ Phenols $\uparrow$ & \\
& Ta077 & 12 & $\mathrm{P} \uparrow$ & \\
& Ta133 & 12 & $\mathrm{P} \uparrow$ & \\
Apr./09 & Ta275 & 12 & $\mathrm{P} \uparrow \mathrm{Phenols} \uparrow$ & $\mathrm{Fe}$ \\
& Ta004 & 12 & $\mathrm{P} \uparrow$ & $\mathrm{Fe}$ \\
June/09 & Ta275 & 12 & & $\mathrm{Fe}$ \\
& Ta004 & 9 & & $\mathrm{Fe}$ \\
& Ta133 & 12 & $\mathrm{Fe}, \mathrm{Mn}$ \\
Dec./09 & Ta275 & 12 & $\mathrm{Pe} \uparrow$ & $\mathrm{Fe}$ \\
& Ta004 & 12 & & \\
\hline
\end{tabular}

were not in accordance with the law and coincided with this delay.

Variations in metal contents were detected during the study, presenting means higher than the standard allowed in Brazil for $\mathrm{Al}$ and Fe. While $\mathrm{Al}$ and $\mathrm{Fe}$ were higher than the legal limit in $100 \%$ of the analyses at all site, $\mathrm{Cu}$ was above the allowed amount only at Ta004 (0.016 mg.L $\mathrm{L}^{-1} /$ Sept./06). Although the mean of $\mathrm{Mn}$ is within the CONAMA standards, occasional results are higher than this standard $\left(0.116 \mathrm{mg} \cdot \mathrm{L}^{-1} / \mathrm{Ta} 004\right.$; $0.101 \mathrm{mg} . \mathrm{L}^{-1} / \mathrm{Ta} 077 ; 0.149 \mathrm{mg} . \mathrm{L}^{-1} / \mathrm{Ta} 133$; $\left.0.137 \mathrm{mg} . \mathrm{L}^{-1} / \mathrm{Ta} 275\right)$. Since this is a conservative metal, its presence should be recorded. Figure 6 shows the mean value of metals with their respective standard deviations. Although $\mathrm{Cr}, \mathrm{Ni}$ and $\mathrm{Pb}$ were researched because they are potential sources of contamination, they were not detected.

\section{Discussion}

Acute actions in Taquari River were found in 9\% of the samples, but analyzing each site individually, this value should rise to $12.5 \%$ at $\mathrm{Ta} 004, \mathrm{Ta} 077$ and Ta133, since each of these sites presented a mortality event higher than expected. An acute effect on test-organisms was only not detected at Ta275 (headwaters). Phosphorus was higher than the legal standard in Brazil (CONAMA, 2005) on several occasions at the points with recorded acute toxicity. At those sites the means and standard deviation were quite high, and the peak was found at Ta133 (0.770 mg.L.-1/Apr.09).

Comparing this sampling cycle to a previous study at the same sites (Terra et al., 2008), a marked recovery of the river quality was found, since previously mortality events were more frequent. While in the first study (Terra et al., 2008), Ta275 exhibited low survival at three samplings with $60 \%$ deaths on one occasion, in this period the site had at least $80 \%$ survivors, and no acute action was indicated. Located at Ta275 in the headwaters zone, this recovery may mean the restoration of the local biota, besides attenuating the migration of pollutants downstream. At the other sites ( $\mathrm{Ta} 004$, $\mathrm{Ta} 077$ and $\mathrm{Ta} 133)$ an acute effect was observed in $12.5 \%$ of the samples as against $30 \%$ ( $\mathrm{Ta} 077$ and Ta275) and 20\% (Ta133) observed previously (Terra et al., 2008). An increased influence of pollutants was only detected at Ta004 (Apr./09) comparing the two studies, and this effect coincided with low precipitation $(10 \mathrm{~mm})$. Lemos and Erdtmann (2000) report similar behavior in a study of Guaiba Hydrographic Basin, the receiving body of Taquari River, ie., greater contamination during low rainfall periods.

Rivers that receive a pollutant load along the course are expected to present more change at the downstream points. However, the large volume of water in the Taquari River, the strong current and the presence of meanders may explain the more stable conditions observed at the mouth, compared to the intermediate sites, possibly due to the dilution or sedimentation of xenobiotics on the banks, when the presence of meanders slows down the current. Besides, point sources of contamination are more concentrated at isolated points, and when they are transported by the current may sediment or dilute due to the large water volume. 

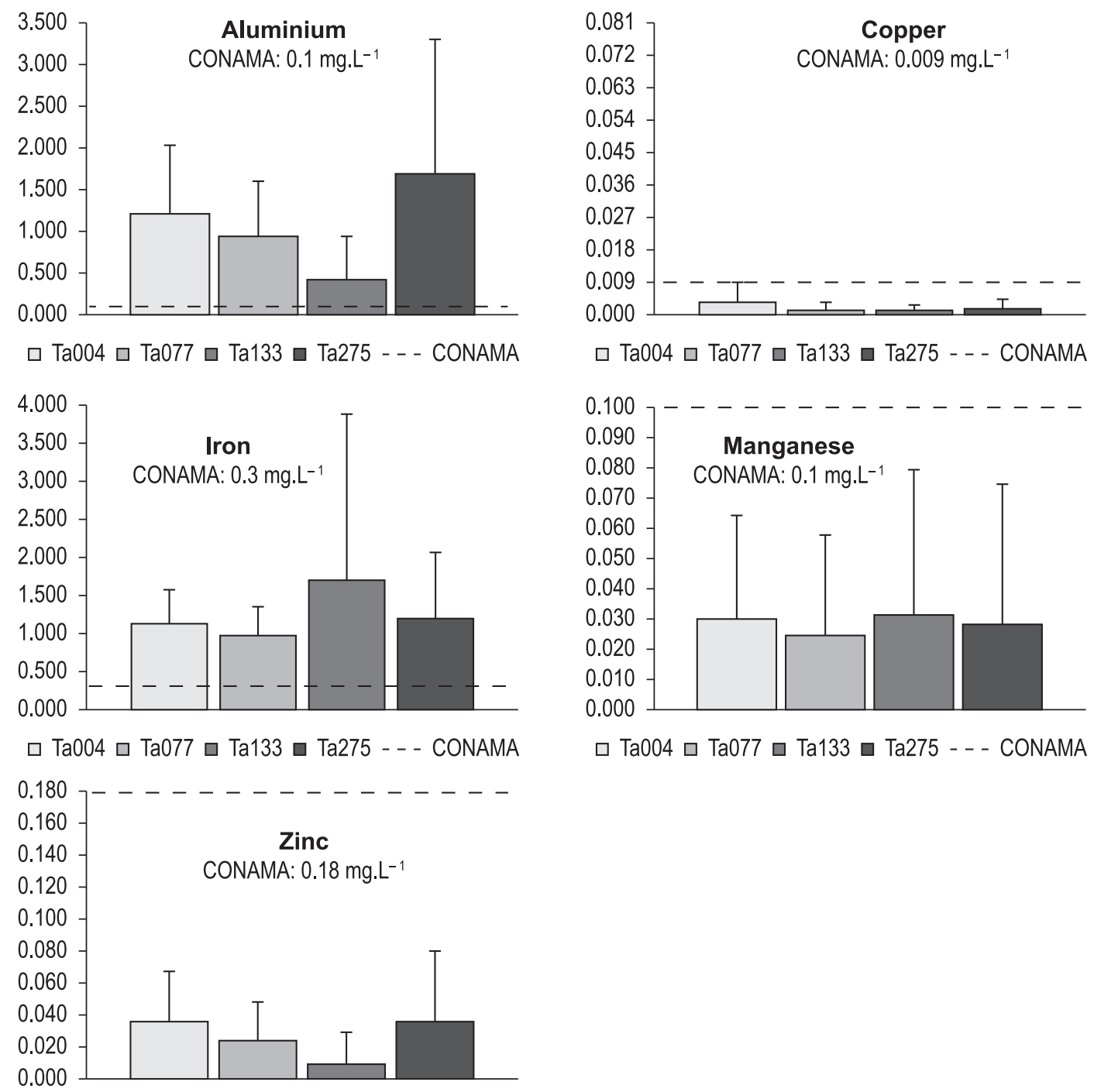

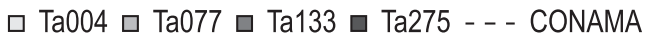

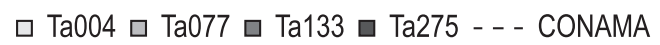

Figure 6. Mean and standard deviation of metals detected at the sites. The broken line shows the standard advocated in Brazil (CONAMA, 2005).

The Spearman correlation ( $\mathrm{p}<0.05)$ was absent when the rainfall index and survival were considered, but the volume of rainfall and the elevation of mortality were seen to coincide. Both situations, drought and flood, can contribute to elevate the toxicity, in the former case because it concentrates pollutants and in the latter because it entrains them from the soil and from upstream areas. The same calculation also did not find a correlation when the points were compared to each other for survival. Spearman correlation $(\mathrm{p}<0.05)$ was also absent for reproduction, coinciding with answers on applying the Duncan Test, when differentiated clusters were formed among the results.

A study performed in Taquari River, between sites Ta004 and Ta077 (Périco et al., 2004), revealed changes in the composition of benthonic fauna related to changes in the quality of sediment in this river. On the other hand, bioassays with samples from the same area presented good conditions for the survival of $D$. magna, but inadequate responses for reproductive activity (Terra et al., 2008) which may disturb the population equilibrium.

While the increased mortality is related to point and high sources of pollutants, reproductive disturbances are observed in the presence of low doses of contaminants, especially when these substances are conservative, such as heavy metals, PAHs and pesticides. Ratte (1996) says that the effect of a toxic product can vary due to differences in the environment, and the magnitude of the response varies according to whether reproduction or survival is being considered. 
Comparing data from sediment samples collected between 2000 and 2004 (Terra et al., 2008) to the current ones, resemblances were observed in the reproductive activity. While in first period changes occurred in the generation of neonates in $90 \%$ of the samples, in the second period changes at a reproductive level were found in $91 \%$ of the samples. These data show that contaminants are still being released into the river, whether it be through effluents with partial treatment, soil entrainment as a result of rainfall or other natural pathways. However, when the acute results are considered, it can be supposed that the pollutant load has been diminishing, since a marked improvement of survival was observed.

Ta004 (Dec./09) and Ta077 (June/06; Apr./10) attained the expected values for births at samplings spread out over the years, different from the first stage of evaluation (Terra et al., 2008) when the absence of chronic toxicity was concentrated in the last month sampled (Sept./05) for all sites.

A significant difference $(\mathrm{p}<0.05)$ in the total generation of neonates was observed through Test T. Ta133 presented the lowest sum of individuals born (4,383 org) among all the samples processed, with the lowest mean births. The most productive site was Ta077 corresponding to the highest mean births, followed by Ta004 and Ta275 sites located at the mouth and in the headwaters, respectively.

The smallest standard deviation was found at Ta275 and the greatest at Ta133. Ta004 and Ta077 showed intermediate values. High standard deviations suggest data variability and this behavior may be related to intermitted point discharge sources. It is interesting to point to Mar./07 when Ta133 presented the highest number of births (836) at this site, corresponding to the month with the greatest rainfall $(265.5 \mathrm{~mm})$ recorded at the site and the second highest in relation to all measurements performed at the four sites. It should, however, be pointed out that it was at $\mathrm{Ta} 077$, in June/06, that the highest production of neonates among all points occurred $(1,040)$ and the third lowest rainfall index $(72.5 \mathrm{~mm})$ of this site.

On some occasions there was a delay in beginning reproductive activity, at the same time as chemical changes, especially increased Phosphorus. Ratte (1996) suggests that the increased time to the first reproduction, even if only for one day, may interfere in the population dynamics of D. magna, concluding that the time of development and reproduction are highly significant for the population dynamics of the species. Besides a delay in beginning reproduction, other major changes were found in this study. Ta275 in ee/06 produced only 13 neonates during the 21 days of exposure, while Ta004, on the ninth day of exposure, generated only five organisms in the only brood laid with the sample of June/09. At the same site (Ta004) an individual generated only three neonates $\left(12^{\text {th }}\right.$ day) when exposed to the sample of Dec./09, and died immediately afterwards. In June/06 at site Ta275, the rainfall index was higher than in the other months. During this period a $\mathrm{P}$ and $\mathrm{pH}$ content above the legal limit was also observed, and a DO below the level advocated by Brazilian law. These changes agree with the phenomena of high rainfall in the river headwaters, that caused the entrainment of soil contaminated by fertilizers and pesticides into water, provoking changes in the organisms and less neonate production, as observed at the site on this occasion. Reis et al. (2010) mentioned the entrainment of soil particles into the river bed during the rainy period, transporting associated metals. Fe and Mn above the legal limits were detected during the months of June/09 and Dec./09 at Ta004.

There was a significant difference $(\mathrm{p}<0.05)$ in the reproduction parameter between the control group and the others when the T Test was used. On the other hand, among the points this difference $(\mathrm{p}<0.05)$ was perceived at Ta004 and at Ta077 (sites further downstream) compared to Ta133 and Ta275 (sites further upstream). Between Ta004 and $\mathrm{Ta} 077$ there was no difference, nor between Ta133 and Ta275, when compared to each other. The similarity between points that are close to each other may involve the water flow besides the local contributions of pollution.

Comparing the monthly means of births at each site (Duncan Test; $\mathrm{p}<0.05$ ), greater variation was observed in June/06, Sept./06, Apr./09 and June/09, forming three clusters, followed by Sept./08 and Dec./09 with two, while Mar./07 and Apr./10 presented only one.

During the acute toxicity episodes ( $\mathrm{Ta} 004 /$ Apr./09, Phosphorus $=0.254$ mg. $\mathrm{L}^{-1} ; \mathrm{Ta} 077 /$ Dec./09, Phosphorus $=0.061$ mg.L $L^{-1} ;$ Ta133/Apr./09, Phosphorus $=0.770 \mathrm{mg} . \mathrm{L}^{-1}$, Phenols $=0.08 \mathrm{mg} . \mathrm{L}^{-1}$ ) the phenol and/or phosphorus values were higher than the Brazilian legal limits (CONAMA, 2005). The mean of $\mathrm{P}$ was above the legal limits at all four sites, while the mean of Phenol was higher than the legal limit only at Ta077, although the standard deviation was higher than the permitted value at all sites. Since Phenol and its byproducts are toxic 
for D. magna (Keen and Baillod, 1985; Kühn et al., 1989) these data must be valued.

Both the production of viable eggs and survival in D. magna are conditioned to the presence of phosphorus, since this mineral is reallocated to the processes of molting and reproduction ( $\mathrm{He}$ and Wang, 2008; Becker and Boersma, 2005). However, it should be underscored that the excess of this element may be related to sanitary sewage discharges or the entrainment of fertilizers that could act on the organism. Ballantine et al. (2009) say that the increased concentration of $\mathrm{P}$ in the sediment is related to land use in agriculture, and that, therefore, it is important to consider the type of soil, land uses and the presence of this mineral. They also call attention to the transport of sediment rich in phosphorus by runoff. This is one of the main routes of this element into the rivers, interfering in their quality, stimulating eutrophication and/or carrying environmental contaminants. Besides this route of contribution to the rivers, He and Wang (2007) highlight the contribution of microcrustacean exuviae to the increased P content in the sediment.

Michaelsen and Freitas (2004) say that seasonality is not a decisive reason for the water quality in Taquari River. They consider anthropic action in the rivers forming them with lower discharge as the main factor responsible for the quality of surface waters, but in this study a Spearman Correlation was detected between rainfall and reproduction at Ta133.

On the other hand at site Ta133 in Dec./09 high values for $E$. coli and phosphorus coincided with incentive in the reproduction of test-organisms. The elevation of these two parameters (E. coli and P) simultaneously, indicates the presence of sanitary sewage. In this case, the greater generation of neonates does not mean environmental recovery but the possibility of site degradation, since the excessive availability of nutrients which initially favors the development of flora and fauna may trigger the environmental eutrophication process, followed by a toxic algal bloom and DO depletion.

Contaminants transported to the river by soil entrainment, effluents or atmospheric route are responsible for variations in the results on metals, some of them (Al, Fe) exhibiting a mean above the Brazilian legal limit at all sites. The means of $\mathrm{Mn}, \mathrm{Cu}$ and $\mathrm{Zn}$ were situated within the standards accepted for Class 2 rivers, although sometimes $\mathrm{Mn}$ and $\mathrm{Cu}$ presented higher values than those advocated. Gillis et al. (2006), in a study on metal- contaminated raw sediments observed a 50\% reduction in the survival of $D$. magna.

Aluminum was detected at all sites at levels higher than the accepted Brazilian standard (CONAMA, 2005, and this metal may be one of the factors responsible for reproductive changes during the exposure of $D$. magna to sediment. Gostomski (1990) reports chronic toxicity of Aluminum for D. magna at $742.2 \mu \mathrm{g} . \mathrm{L}^{-1}$, a value that was surpassed on many occasions during the present study.

De Schamphelaere et al. (2007) say that copper is bioavailable in the aquatic environment, inhibiting $50 \%$ of the reproductive process in daphniids when exposed to the metal, and therefore their presence in natural environments must be evaluated. They also observed that the effects of copper on reproduction are more significant than those related to growth. De Schamphelaere et al. (2007) reported delays in the first reproduction $\left(12^{\text {th }}\right.$ day of exposure), besides other effects after the first brood was released, when D. magna was exposed to this metal. On the other hand, Gutierrez et al. (2010) observed a change in the life cycle, in fertility and in the formation of the first egg sac of the copepode Notodiaptomus conifer (SARS) exposed to copper. Wang et al. (2007), using the same metal $(\mathrm{Cu})$, observed a progressive reduction in the size beginning with the second brood of Moina monogolica Daday. Although few test-organisms responded late in the reproductive process when exposed to sediment samples from the Taquari River, it is necessary to consider the different levels of health and resistance of the organisms that are part of the communities regarding the changes introduced in the ecosystem.

Although the standard deviation for $\mathrm{Cu}$ was located on the line below the legal limit (Ta004), since it is conservative, it should be mentioned that Gillis et al. (2006) looked at the low survival rate $(<50 \%)$ in D. magna exposed to sediment contaminated with $\mathrm{Cu}$, ascribing the action to the water overlying the sediment. In their study, Schamphelaere et al. (2007) considered that the metabolic cost to inhibit the stress caused by $\mathrm{Cu}$ can reduce the reproduction and growth processes, concluding that this metal was responsible for reducing the food ingestion rate in Daphnia magna.

Zinc is an essential metal for living beings, and is highly important in the reproductive process of D. magna (De Schamphelaere et al., 2007); it is easily released from sediment by grazing activity (Twiss and Campbell, 1995). Although it is present in $86 \%$ of the analyses in this study, Zinc always presented values below the level allowed in the law 
for Class 2 waters. Its conservative characteristic makes a record of its presence important, since Gillis et al. (2006) suggest that this metal was responsible for mortality in $D$. magna when it was in the water overlying the sediment.

Lasier et al. (2000) say that $\mathrm{Mn}$ is a toxic element discharged into the environment by many routes including effluents and sediment. They also report its lethal and reproduction-inhibiting capacity in C. dubia and H. azteca. Mejía-Saavedra et al. (2005) verified that $\mathrm{Mn}$ and DDT are toxic for D. magna and act synergistically, emphasizing the importance of a joint evaluation of xenobiotics, since the environment is a complex mixture of substance. In this study, although the mean of $\mathrm{Mn}$ was within the standard required in Brazilian law, some results went over it.

Iron was detected above the legal limit of Brazilian law for Class 2 waters, in all samples. Although it is an essential nutrient its presence in excess causes physiological changes in the individual. Vuori (1995) considers that the increased Fe in the environment may significantly alter the structure and function of lotic ecosystems. He also points out that precipitates of this metal onto animals cause qualitative and quantitative changes in the dietary behavior. Van Anholt et al. (2002) perceived a strong reduction of the offspring viability, diminished growth, as well as raised mortality of D. magna, at sites with a high concentration of iron. The same authors say that iron-contaminated food and complex metals may interfere in their intake by filtering individuals, and conclude that although they found acute action, chronic and sublethal effects such as the reduced viability of offspring of water fleas were recorded.

Crop diversity in Taquari River valley is certainly the main factor responsible for responses observed in this study. According to Tonietto et al. (2004), the presence of vineyards may have contributed to bad water quality because of pesticides at site Ta275. The use of different agricultural pesticides (pyrethroid, organochlorine and organophosaphate) in the region (CRQ, 2008) helps explain some alterations observed. Duquesne (2006) cites that organophosphates at sub-lethal concentrations may induce changes in the population of D. magna with a decrease in the mean number of neonates and delay in beginning reproduction, with heavy costs to the ecosystem due to the reflexes triggered at upper trophic levels. In the same study the author says that in chronic assays this pesticide caused high mortality in the first seven days of species exposure, and its action is diminished from the $8^{\text {th }}$ to the $21^{\text {st }}$ day. Ren et al. (2009) recorded changes in the movements of $D$. magna in the presence of organophosphates, even at low concentrations, although they emphasized a strong resistance among the survivors. The same authors mention neurotoxic signals of this species when exposed to deltametrin, a pyrethroid used in the Taquari River valley, referring to similarity between the response to this pesticide and to organophosphates. Ren et al. (2009a) propose the use of D. magna to evaluate samples contaminated by organophosphates because they are sensitive bioindicators for this group of pesticides. Barry (1996) found a reduction in the alimentary rate, increased metabolic loss, besides delay in the reproductive maturity of Daphnia when exposed to organochlorines. Thus, it is appropriate to use this daphniid to evaluate the Taquari River sediment, since it is an area subject to contamination by these active principles.

When PAHs, another group of contaminants identified in samples collected in the area, especially close to Taquari River mouth, according to Gewurtz et al. (2000) accumulates at lower trophic levels, they can be transferred to fish and birds that complement their diets with benthonic invertebrates. The concentration varies according to the alimentary habit of the species. Since fish is an important food for humans and one of the main sources of protein for the riparian population, the presence of these contaminants should be considered when evaluating the toxicological stress on the aquatic ecosystem. Chen (2007) emphasizes the world interest in pollution caused by PAHs, due to their wide distribution, highlighting their tendency to accumulate in the trophic chain. According to Pickard et al. (2006), these compounds tend to be persistent and are adsorbed to the sediment and organic carbon. Moreover, the bioavailability of PAHs determined the potential for bioaccumulation and toxicity to organisms. Among the products that release PAHs is the creosote (Pickard et al., 2006) utilized by a company located in an area close to Taquari River mouth between 1982 and 1998. During that period, losses of product (creosote and pentachlorophenol) used to treat the wood poles by this company contaminated the soil, small streams and lagoons located around it, and may have reached the Taquari River (multidisciplinary study ongoing). Chen (2007) considers even the surface waters, atmospheric precipitation, run-off, spills and/or leakage of oil, municipal and industrial effluents as PAHs dispersion routes. Since they are 
semi-volatile organic compounds they are present among the gases and particles of air contaminating the soil during the rainfall, this is probably one way for contaminants to reach the area.

The variety of point and diffuse sources of contamination along the Taquari River is responsible for changes observed in this study. Robinson et al. (2010) concluded that the time of organism exposure to contaminated sediment is more important than the quantity of suspended particles, and thus responses at a chronic level were expected in this study due to the time of exposure (21 days). Studies repeated with samples of water, sediment, or even at low doses of toxic products, have shown the importance of long-duration assays. Robinson et al. (2010) say that a longer time of exposure, using low concentrations of toxic products, shows a decrease in the size of organisms compared to 24 hours exposures.

The reduction of neonates at high levels was found in this study repeating information about previous work in the same field (Terra et al., 2008). The chronic toxicity seen reveals the need for constant follow up of this river and its tributaries throughout its course.

Chronic bioassays are ideal tools to learn about hydrographic basins, since, while survival pointed to rare moments of change in the environmental quality, reproduction showed constant responses to the pollutants discharged in the region.

\section{Acknowledgements}

This research was funded by FEPAM. The authors wish to thank the Sampling Sector at FEPAM, the Conselho Nacional de Desenvolvimento Científico e Tecnológico (CNPq) for the ATP-A scholarships (Processo no 371743/2009-5) given to Ilda Rosa Feiden and ATP-A (Processo n³71290/2010-4) given to Fabiane Lucheta, besides the Scientific Initiation scholarships (Processes no 104342/20099 and 108460/2009-6) granted to Silvana Pereira Gonçalves; the Fundação Estadual de Pesquisa Agropecuária (FEPAGRO) and Defesa Civil do Rio Grande do Sul (www2.defesacivil.rs.gov.br/ estatistica/pluviometro_consulta.asp) for the rainfall data. The values informed for heavy metals, physical, chemical and microbiological parameters were obtained from the FEPAM Database.

\section{References}

American Public Health Association - APHA. 1992. Standard methods for the examination of water and wastewater. 18th ed. Washington: APHA.
Associação Brasileira de Normas Técnicas-ABNT. 2004. NBR 12713: Ecotoxicologia aquática - Toxicidade aguda - Método de ensaio com Daphnia spp (Cladocera, crustacea). 2. ed. ABNT.

BALLANTINE, D., WALLING, DE. and LEEKS, GJL. 2009. Mobilisation and transport of sediment - associated phosphorus by surface runoff. Water Air and Soil Pollution, vol. 196, no. 1-4, p. 311-320. http://dx.doi.org/10.1007/s11270-008-9778-9

BARRY, MJ. 1996. Effects of an Organochlorine Pesticide on Different Levels of Biological Organization in Daphnia. Ecotoxicology and Environmental Safety, vol. 34, no. 3, p. 239-251. http://dx.doi. org/10.1006/eesa.1996.0069

BECKER, C. and BOERSMA, M. 2005. Differential effects of phosphorus and fatty acidson Daphnia magna growth and reproduction. Limnology and Oceanography, vol. 50, no. 1, p. 388-397. http:// dx.doi.org/10.4319/lo.2005.50.1.0388

CHEN, HW. 2007. Distribution and Risk Assessment of Polycyclic Aromatic Hydrocarbons in Household Drinking Water. Bulletin of Environmental Contamination and Toxicology, vol. 78, p. 201-205. http://dx.doi.org/10.1007/s00128-007-9124-8(F40)

Conselho Nacional do Meio Ambiente-CONAMA. 2005. Resolução no. 357, de 17 de Março de 2005. Dispóe sobre a classificação dos corpos de água e diretrizes ambientais para o seu enquadramento, bem como estabelece as condiçóes e padróes de lançamento de efluentes, e dá outras providências. Diário Oficial da República Federativa do Brasil, Poder Executivo, Brasília, DF, 17 abr. 2005. Available from: <http:// www.mma.gov.br>. Access in: 17abr. 05

Conselho Regional de Química - CRQ-V. 2008. I Mapeamento dos agrotóxicos utilizados no Rio Grande do Sul. Porto Alegre: CRQ-V.

DE SCHAMPHELAERE, KAC., FORREZ, I., DIERCKENS, K., SORGELOOS, P. and JANSSEN, CR. 2007. Chronic toxicity of dietary cooper to Daphnia magna. Aquatic Toxicology, vol. 81, no. 4, p. 409-418. http://dx.doi.org/10.106/j. aquatox.2007.01.002

DUQUESNE, S. 2006. Effects of an organophosphate on Daphnia magna at suborganismal and organismal levels: Implications for populations dynamics. Ecotoxicology and Environmental safety, vol. 65, no. 2, p. 145-150. http://dx.doi.org/10.1016/j. ecoenv.2006.01.008

ELENDT, BP. and BIAS, WR. 1990. Trace nutrient deficiency in Daphnia magna cultured in standard medium for toxicity testing. Effects of the optimization of culture conditions on life history parameters of $D$. magna. Water Research, vol. 24, no. 9, p. 1157-1167. http://dx.doi.org/10.1016/0043-1354(90)90180-E

FERREIRA, ER. and BOTH, GC. 2004. Programa de alerta de enchentes da bacia do rio Taquari-Antas/RS. 
In Anais do IV Simpósio Internacional de Qualidade Ambiental, 2004. Porto Alegre. Tema 6, trabalho 185. Tema Sistemas de gestão ambiental e de certificaçáo $\mathrm{t} 185$.

GEWURTZ, SB., LAZAR, R. and HAFFNER, GD. 2000. Comparison of Polycyclic Aromatic Hydrocarbon and polychlorinated biphenyl dynamics in benthic invertebrates of lake Erie, USA. Environmental Toxicology and Chemistry, vol. 19, no. 12, p. 2943-2950. http://dx.doi.org/10.1002/ etc. 5620191215

GILLIS, PL., WOOD, CM., RANVILLE, JF. and CHOW-FRASER, P. 2006. Bioavailability of sediment - associated $\mathrm{Cu}$ and $\mathrm{Zn}$ to Daphnia magna. Aquatic Toxicology, vol. 77, no. 4, p. 402-411. http:// dx.doi.org/10.1016/j.aquatox.2006.01.010

GOSTOMSKI, F. 1990. The toxicity of aluminum to aquatic species in the US. Environmental Geochemistry and Health, vol. 12, no. 1-2, p. 51-54. http://dx.doi. org/10.1007/bf01734047

GUTIERREZ, MF., GAGNETEN, AM. and PAGGI, JC. 2010. Copper and chromium alter life cycle variables and the equiproportional development of the freshwater copepod Notodiaptomus conifer (SARS). Water Air and Soil Pollution, vol. 213, no. 1-4, p. 275-286. http://dx.doi.org/10.1007/ s11270-010-0383-3

HAMILTON, MA., RUSSO, RC. and THURSTON, RV. 1977. Trimmed Spearman-Karber method for estimating median lethal concentrations in toxicity bioassays. Environmental Science Technology, vol. 11, no. 7, p. 714-719. http://dx.doi.org/10.1021/ es60130a004

HE, X. and WANG, W-X. 2007. Kinetics of phosphorus in Daphnia at different food concentrations and carbon: phosphorus ratios. Limnology and Oceanography, vol. 52, no. 1, p. 395-406. http:// dx.doi.org/10.4319/lo.2007.52.1.0395

HE, X. and WANG, W-X. 2008. Stoichiometric regulation of carbon and phosphorus in P. deficient Daphnia magna. Limnology and Oceanography, vol. 53, no. 1, p. 244-254. http://dx.doi.org/10.4319/ lo.2008.53.1.0244

KEEN, R. and BAILLOD, CR. 1985. Toxicity to Daphnia of the end products of wet oxidation of phenol and substituted phenols. Water Research, vol. 19, no. 6, p. 767-772. http://dx.doi.org/10.1016/00431354(85)90125-3

KÜHN, R., PATTARD, M., PERNAK, K-D. and WINTER, A. 1989. Results of the harmful effects of selected water pollutants (Anilines, phenols, aliphatic compounds) to Daphnia magna. Water Research, vol. 23, no. 4, p. 495-499. http://dx.doi. org/10.1016/0043-1354(89)90141-3

LASIER, PJ., WINGER, PV. and BOGENRIEDER, KJ. 2000. Toxicity of Manganese to Ceriodaphnia dubia and Hyalella azteca. Environmental Contamination and Toxicology, vol. 38, no. 3, p. 398304. http://dx.doi.org/10.1007/s0024499100039

LEMOS, CT. and ERDTMANN, B. 2000. Cytogenetic evaluation of aquatic genotoxicity in human cultured lymphocytes. Mutation Research, vol. 467, no. 1, p. 1-9. http://dx.doi.org/10.1016/S13835718(00)00009-7

MEJÍA-SAAVEDRA, J., SÁNCHEZ-ARMASS, S., SANTOS-MEDRANO, GE., GONZÁLESAMARO, R., RAZO-SOTO, I., RICO-MARTÍNEZ, R. and DÍAZ-BARRIGA, F. 2005. Effect of coexposure to ddt and manganese on freshwater invertebrates: pore water from contaminated rivers and laboratory studies. Environmental Toxicology and Chemistry, vol. 24, no. 8, p. 2037-2044. http:// dx.doi.org/0.1897/04-438R

MICHAELSEN, BL. and FREITAS, KW. 2004. Gestão da qualidade das águas no complexo energético rio das Antas. In Anais do IV Simpósio Internacional de Qualidade Ambiental, 2004. Porto Alegre. Tema 6, trabalho 280. Tema Sistemas de gestáo ambiental e de certificação.

PÉRICO, E., LIMA, DFB., CEMIM, G., GUIMARÃES, AA., DIEDRICH, VL., OST, E. and REMPEL, C. 2004. Utilização de sistema de informação geográfica e de macroinvertebrados bentônicos para avaliaçáo do estado de conservação das matas ripárias da bacia do rio Taquari - segmento de Muçum a Taquari, RS. In Anais do IV Simpósio Internacional de Qualidade Ambiental, 2004. Porto Alegre. Tema Sistemas de gestão ambiental e de certificação t265

PICKARD, SW., CLARKE, JU. and LOTUFO, GR. 2006. Bioavailability of polycyclic aromatic hydrocarbons (PAHs) from surficial lake Erie sediments. Bulletin Environmental Contamination and Toxicology, vol. 76, no. 5, p. 791-798. http:// dx.doi.org/10.1007/s00128-006-0989-8

RATTE, HT. 1996. Statistical implications of end-point selection and inspection interval in the Daphnia reproduction test - A simulation study. Environmental Toxicology and Chemistry, vol. 15, no. 10, p. 18311843. http://dx.doi.org/10.1002/etc.5620151026

REIS, A., PARKER, A. and ALENCOÃO, A. 2010. Avaliação da qualidade de sedimentos em rios de montanha: um caso de estudo no norte de Portugal. Recursos Hidricos, vol. 31, no. 1, p. 87-97.

REN, Z-M., LI, Z-L., ZHA, J-M., RAO, K-F., MA, M., WANG, Z. and FU, R-S. 2009. The avoidance responses of Daphnia magna to the exposure of organophosphorus pesticides in an on-line biomonitoring system. Environmental Modeling and Assessment, vol. 14, no. 3, p. 405-410. http://dx.doi. org/10.1002/etc. 4

REN, Z., LI, Z., MA, M., WANG, Z. and FU, R. 2009a. Behavioral responses of Daphnia magna to stresses of chemicals with different toxic characteristics. 
Bulletin of Environmental Contamination and Toxicology, vol. 82, no. 3, p. 310-316. http://dx.doi. org/10.1007/s00128-008-9588-1

ROBINSON, SE., CAPPER, na. and KLAINE, sj. 2010. The effects of continuous and pulsed exposures of suspended clay on the survival, growth, and reproduction of Daphnia magna. Environmental Toxicology and Chemistry, vol. 29, no. 1, p. 168-175. http://dx.doi.org/10.1002/etc.4

SUEDEL, BC., DEAVER, E. and ROGERS JUNIOR, JH. 1996. Experimental factors that may affect toxicity of aqueous and sediment-bound copper to freshwater organisms. Archives Environmental Contamination and Toxicology, vol. 30, no. 1, p. 4046. http://dx.doi.org/10.1007/BF00211327

TERRA, NR., FEIDEN, IR. and FACHEL, JMG. 2008. Taquari River (Rio Grande do Sul, Brazil) sediment ecotoxicology, using Daphnia magna, 1820, Straus as test organism. Acta Limnologica Brasiliensia, vol. 20, no. 2, p. $153-159$.

TONIETTO, J., GARRIDO, L., SÔNEGO, OR., MORAES, OLL., ACEVEDO, OC. and HASENACK, H. 2004. Monitoramento e avaliação do impacto de alteraçóes climáticas do complexo energético do rio das Antas na viticultura da serra gaúcha. In Anais do IV Simpósio Internacional de Qualidade Ambiental, 2004. Porto Alegre. Tema 6, trabalho 303. Tema Sistemas de gestáo ambiental e de certificação.

TWISS, MR. and CAMPBELL, PGC. 1995. Regeneration of trace metals from picoplankton by nanoflagellate grazing. Limnology and Oceanography, vol. 40, no. 8, p. 1418-1429. http://dx.doi. org/10.4319/lo.1995.40.8.1418
VAN ANHOLT, RD., SPANINGS, FAT., KNOL, AH., VAN DER VELDEN, JA. and WENDELAAR, BONGA, SE. 2002. Effects of iron sulfate dosage on the water flea (Daphnia magna Straus) and early development of carp (Cyprinus carpio L.). Archives of Environmental Contamination and Toxicology, vol. 42, no. 2, p.182-192. http://dx.doi.org/10.1007/ s00244-001-0001-x

VUORI, KM. 1995. Direct and indirect effects of iron on river ecosystems. Annales Zoologici Fennici, vol. 32, no. 3, p. 317-329.

WANG, Z-S., KONG, H-N. and WU, D-Y. 2007. Reproductive toxicity of dietary copper to a saltwater cladoceran, Moina monogolica daday. Environmental Toxicology Chemistry, vol. 26, no. 1, p. 126-131. http://dx.doi.org/10.1897/06-216R1.1

WELTENS, R., GOOSSENS, R. and PUYMBROECK, SV. 2000. Ecotoxicity of contaminated suspended solids for filter feeders (Daphnia magna). Archives of Environmental Contamination and Toxicology, vol. 39, no. 3, p. 315-323. http://dx.doi.org/10.1007/ s002440010110

YU, R-Q. and WANG, W-X. 2002. Trace metal assimilation and release budget in Daphnia magna. Limnology and Oceanography, vol. 47, no. 2, p. 495504. http://dx.doi.org/10.4319/lo.2002.47.2.0495

ZANOTELLI, ML., STÜLP, S., ETHUR, EM., PASSOS, IS., MARMITT, S. and CARAMÃO, EB. 2004. Análise de pesticidas organofosforados em sedimentos dos recursos hídricos do vale do Taquari. In Anais do IV Simpósio Internacional de Qualidade Ambiental, 2004. Porto Alegre. Tema 6, trabalho 332. Tema Sistemas de gestáo ambiental e de certificação $t 33$. 